
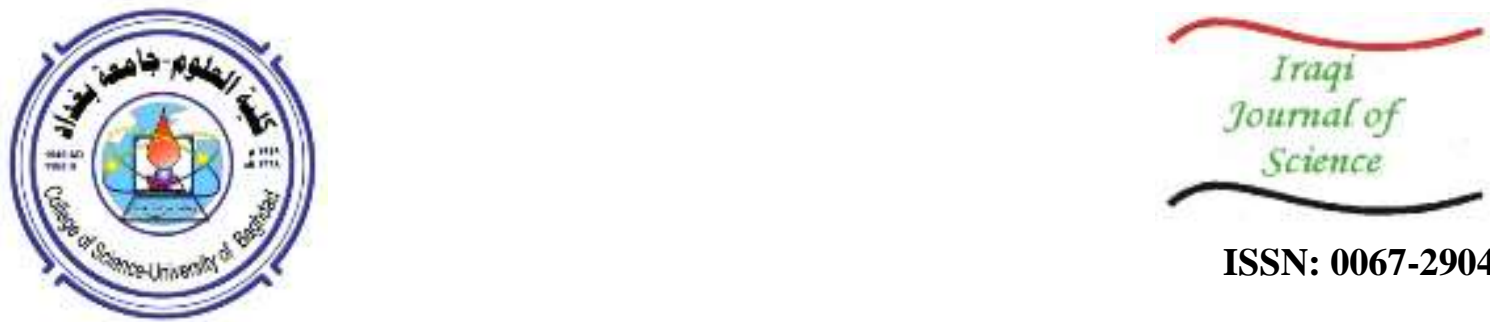

ISSN: 0067-2904

\title{
First Record of Streaked Rabbitfish Siganus Javus (L., 1766) from the Iraqi Marine Waters, with Re Description of White-Spotted Rabbitfish Siganus Canaliculatus (Park, 1797)
}

\begin{abstract}
Abbas J. Al-Faisal ${ }^{{ }^{*}}$, Ahmed CH. Al-Shamary ${ }^{1}$, Usamah H.Yousif ${ }^{2}$, Kadhim H. Younis ${ }^{1}$
${ }^{1}$ Marine Science Centre, University of Basrah, Basrah, Iraq

${ }^{2}$ College of Science, University of Basrah, Basrah, Iraq

Abstract

Two Siganid fishes were described in the current study, the first one is Siganus javus (Linnaeus, 1766) as a new record and the other Siganus canaliculatus (Park, 1797), which was collected from the Iraqi marine waters. The samples were collected during December 2018. Streaked rabbitfish $S$. javus is diagnosed by a deep body, $54.01 \%$ in standard length, depth of caudal peduncle, $7.27 \%$, total gill rakers 19 and silvery blue undulating lines on mid and lower sides of the body. Whereas the body depth of White-spotted rabbitfish $S$. canaliculatus was $39.08-42.66 \%$, Caudal peduncle depth ranged from 5.21 to $5.66 \%$, total gill rakers ranged from 22 to 24 and it is distinguished by a numerous pearly blue to whitish spots on the nape and trunk.
\end{abstract}

Keywords: new record, fish, Siganidae, Iraq.

\section{تسجيل اول لاسماك الصافي الجاوي Siganus javus (L., 1766) في المياه البحرية العراقية،

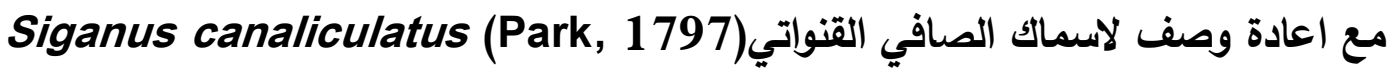

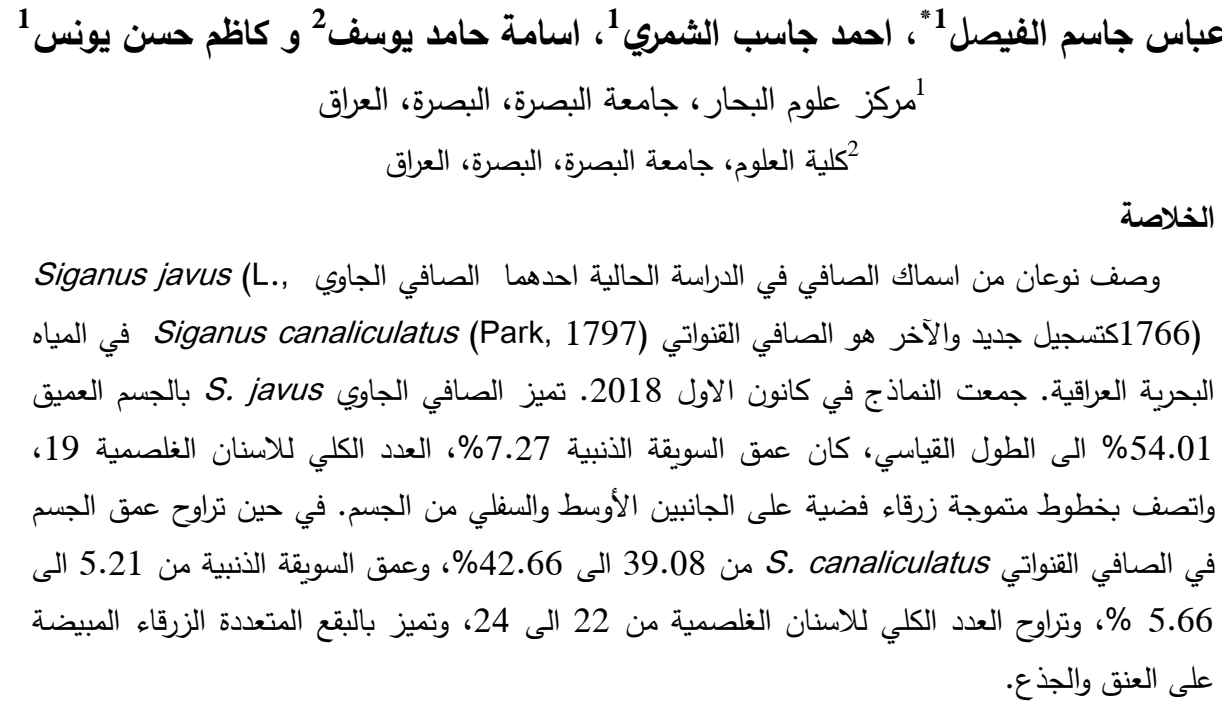

\section{Introduction}

The family Siganidae is composed of one genus (Siganus) with 29 species, that are distributed in Indo-Pacific and eastern Mediterranean [1]. Siganids get their common name, rabbitfishes, from their peaceful temperament, rounded blunt snout, and rabbit-like appearance of the jaws. Rabbitfishes are 
marine and mainly inhabit reefs, shallow lagoons, sea grasses or mangrove areas. Most siganids are herbivorous. Of all species, 13 are schooling species, while the remainder lives among the coral. Individuals of several species may occur in estuaries for part of their life [2].

Siganidae is distinguished by body laterally compressed, oval, deep, or slender, mouth terminal, very small. Single row of compressed, incisiform teeth in both jaws. Pelvic fins each with two strong spines and three soft rays between them, a character unique to this family. Single dorsal fin with 13 strong spines and 10 soft rays. Anal fin with seven strong spines and nine soft rays. Scales cycloid and very small [3].

Three species are reported in the Arabian Gulf, Siganus canaliculatus, S. javus and S. luridus. The first species is the most common and economically important, whereas the second was less common in the commercial catch and the third was relatively smaller in size [4].

The previous studies appeared existence one siganid species, $S$. canaliculatus in the Iraqi marine waters [5- 8]. In this study, we described Siganus javus, as a new record and S. canaliculatus from the Iraqi marine waters.

\section{Materials and Methods}

Four specimens of rabbitfish fish (one of $S$. javus and three of $S$. canaliculatus) were collected

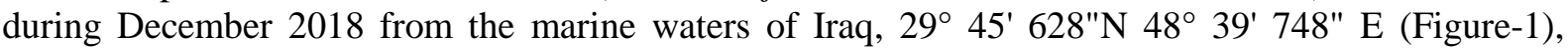
depending on commercial fishery, by using trawl net. The specimens are deposited in the department of Marine Vertebrates, Marine Science Centre, Iraq. The morphological characteristics included eight meristic characters (dorsal fin spines, dorsal fin rays, anal fin spines, anal fin rays, pectoral fin rays, pelvic fin rays and gill rakers) which counted employing dissection microscope, and 18 morphometric characters were measured to the nearest $\mathrm{mm}$ by using digital caliper and fish measuring board following [9]. All morphometric measurements were the percentage of standard length.

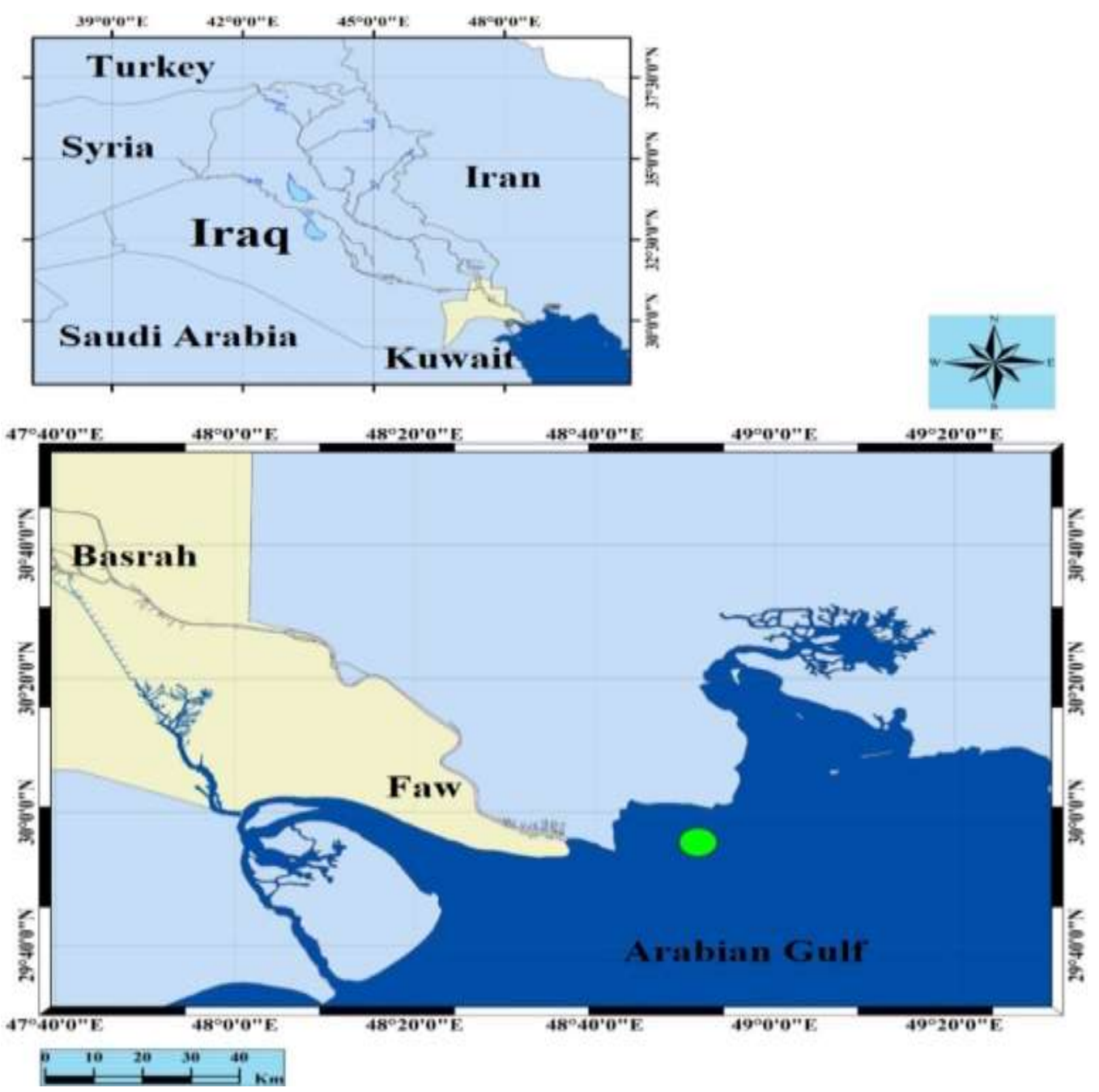

Figure 1- A map showing fishing area in the Iraqi marine waters 


\section{Results and discussion}

Tables-(1,2) showed Morphometric and Meristic characteristics of Siganus javus as a new record from the Iraqi marine waters, and Siganus canaliculatus, which belong to the following classification section:

Class: Actinopterygii

Order: Perciformes

Family: Siganidae

Genus: Siganus Forsskål, 1775

Species 1: Siganus javus (L., 1766)

Synonym:Teuthis javus L., 1766

Amphacanthus javus (L., 1766)

Amphacanthus Javanus (L., 1766)

Siganus java (L., 1766)

Theutis java L., 1766

Species 2: Siganus canaliculatus (Park, 1797)

Synonym:Chaetodon canaliculatus Park, 1797

Siganus oramin (Bloch \& Schneider, 1801)

Amphacanthus dorsalis Valenciennes, 1835

Teuthis dorsalis (Valenciennes, 1835)

\section{Siganus javus (L., 1766)}

\section{Systematics}

This species was originally described in the genus Teuthis L., 1766. Taylor [10] pointed out that rivulatus had already been designated as type of Siganus by Gill, [11]. Gill's designation in fact made Siganus a junior subjective synonym of Teuthis L., 1766 because the type of Teuthis (T. javus L., 1766) is congeneric with the type of Siganus [12].

\section{Materials examined}

MSCUB, $138 \mathrm{~mm} \mathrm{SL}$, northwest of the Arabian Gulf, Iraq, $29^{\circ} 45^{\prime} 628^{\prime \prime} \mathrm{N} 48^{\circ} 39^{\prime} 748^{\prime \prime} \mathrm{E}$, trawl net, December 2018 (Figure-2).

\section{Morphological description}

Total length of the specimen was $183 \mathrm{~mm}$, standard length was $138 \mathrm{~mm}$. Body deep, $54.01 \%$ in standard length and compressed, $14.52 \%$. Snout short, $11.31 \%$. Head length was $28.99 \%$. Dorsal fin length was $70.91 \%$ and its dorsal profile slightly concave above the orbit. Pelvic fin length was $19.97 \%$. Caudal peduncle depth was $7.27 \%$. Dorsal fin with 13 spines followed by 10 rays, fourth to sixth dorsal-fin spine longest. The anal fin had seven spines followed by nine rays, all anal fin spines of similar length and subequal to or slightly shorter than longest anal fin spine. Pelvic fin with two strong spines and three soft rays between them. The total gill rakers were 19. The color of the specimen was back dark bronze, to paler below, numerous metal blue spots on the head and upper sides, silvery blue undulating lines on mid and lower sides of the body.

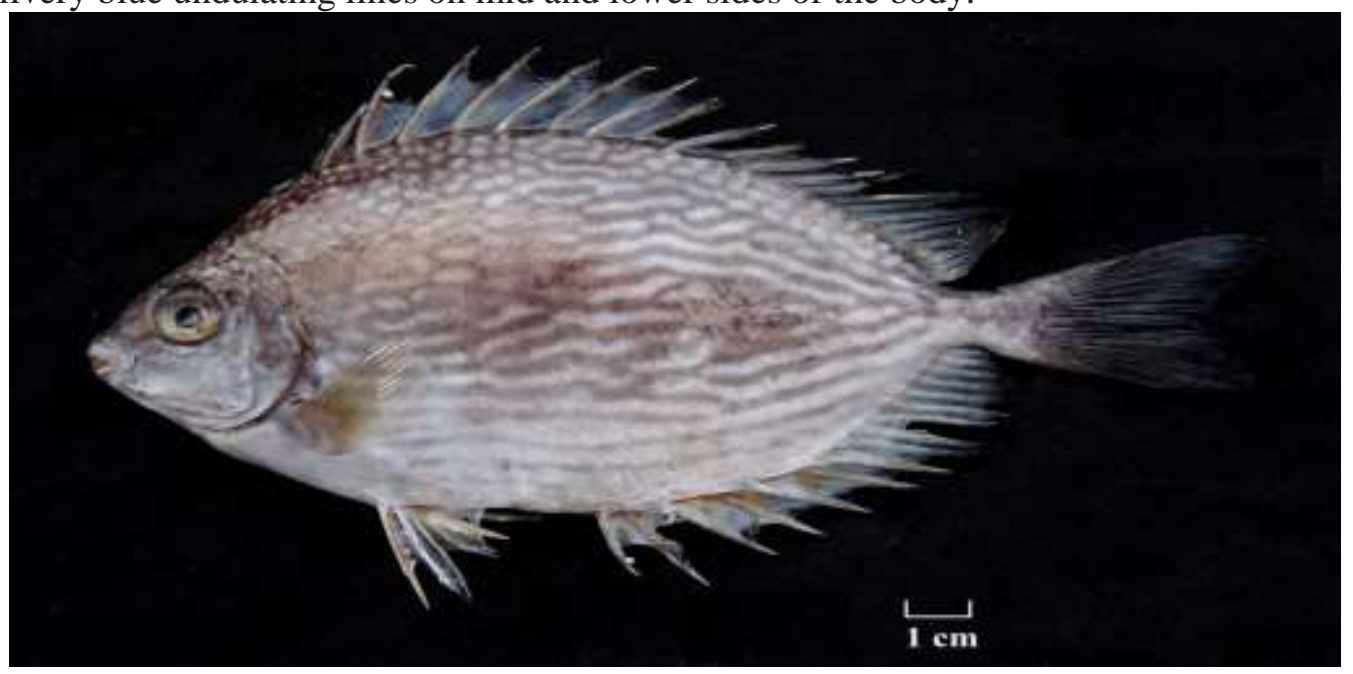

Figure 2- Siganus javus from the Iraqi marine waters. 


\section{Siganus canaliculatus (Park, 1797)}

\section{Systematics}

This species was originally described in the genus Chaetodon L., 1758, which belong to Chaetodontidae. Siganidae is distinguished by Pelvic fins each with two strong spines and three soft rays between them.

\section{Materials examined}

MSCUB, $168 \mathrm{~mm} \mathrm{SL}$, northwest of the Arabian Gulf, Iraq, $29^{\circ} 45^{\prime} 628^{\prime \prime} \mathrm{N} 48^{\circ} 39^{\prime} 748^{\prime \prime} \mathrm{E}$, trawl net, December 2018 (Figure-3).

\section{Morphological description}

The total length of the $S$. canaliculatus ranged from 183 to $228 \mathrm{~mm}$, standard length ranged from 135 to $168 \mathrm{~mm}$. Body compressed $13.32-13.87 \%$ in standard length, its depth $39.08-42.66 \%$. Head profile slightly to markedly concave above the eye, its length ranged from 27.02-27.96\%. Snout pointed, its length $10.32-11.35 \%$. Caudal peduncle depth ranged from 5.21 to $5.66 \%$. Pelvic fin length ranged from 13.72 to $15.49 \%$. Dorsal fin length ranged from 71.43 to $74.19 \%$, it contained 13 spines followed by 10 rays, fourth to seventh dorsal fin spine longest. Anal fin had seven spines followed by nine rays. Pelvic fin with two strong spines and three soft rays between them. The total gill rakers ranged from 22 to 24 . The color was silvery grey above to silvery below with a touch of green on the nape and upper surface of the head, numerous pearly blue to whitish spots on the nape and trunk.

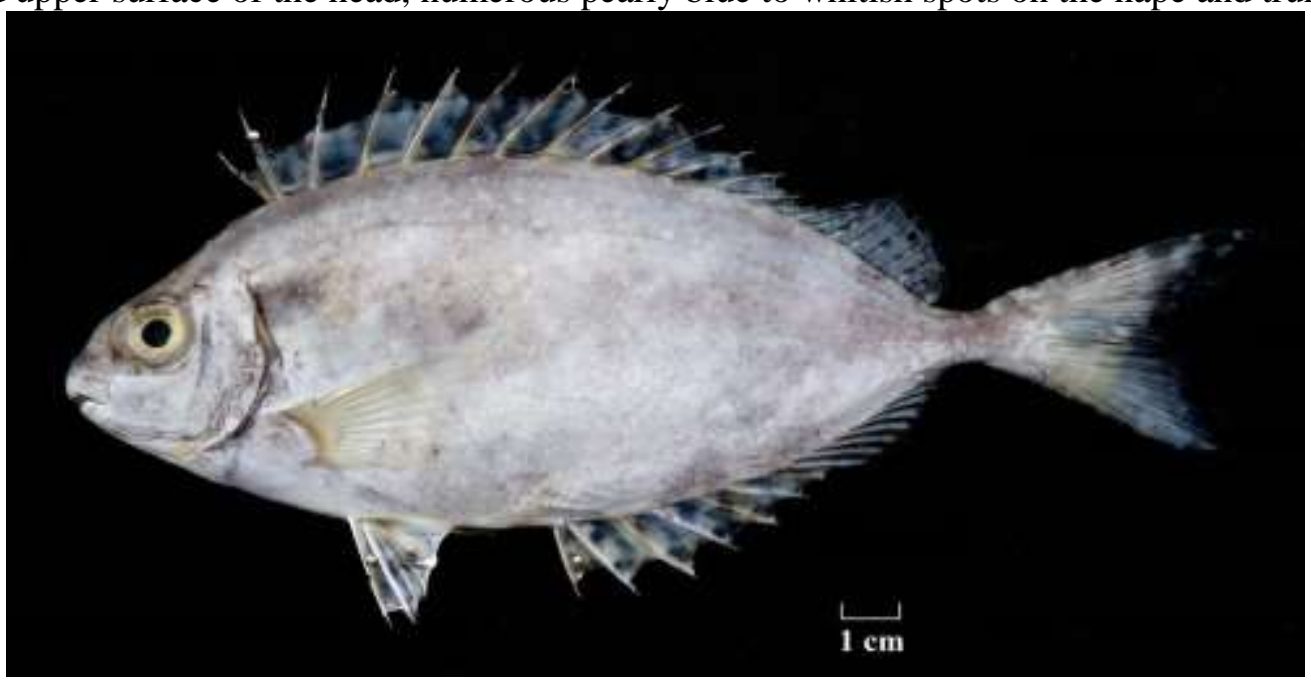

Figure 3- Siganus canaliculatus from the Iraqi marine waters.

Table 1- Morphometric characters of S. javus and S. canaliculatus.

\begin{tabular}{|c|c|c|}
\hline Morphometric characters & S. javus & S. canaliculatus \\
\hline Total length (mm) & 183 & $183-228$ \\
\hline Standard length [SL] (mm) & 138 & $135-168$ \\
\hline Body depth \% in SL & 54.01 & $39.08-42.66$ \\
\hline Body width \% in SL & 14.52 & $13.32-13.87$ \\
\hline Head length \% in SL & 28.99 & $27.02-27.96$ \\
\hline Head depth \% in SL & 27.32 & $21.89-24.89$ \\
\hline Head width \% in SL & 14.06 & $11.77-13.24$ \\
\hline Snout length \% in SL & 11.31 & $10.32-11.35$ \\
\hline Eye diameter \% in SL & 7.87 & $6.99-7.68$ \\
\hline Interorbital distance \% in SL & 7.54 & $6.93-7.46$ \\
\hline Predorsal length \% in SL & 28.89 & $26.98-27.24$ \\
\hline Postdorsal length \% in SL & 6.60 & $6.36-6.58$ \\
\hline
\end{tabular}




\begin{tabular}{|c|c|c|}
\hline fin length\% in SL Dorsal & 70.91 & $71.43-74.19$ \\
\hline Anal fin length \% in SL & 46.31 & $43.41-44.52$ \\
\hline Pectoral fin length \% in SL & 25.12 & $22.36-26.19$ \\
\hline Pelvic fin length \% in SL & 19.97 & $13.72-15.49$ \\
\hline Caudal peduncle length \% in SL & 8.68 & $8.13-9.50$ \\
\hline Caudal peduncle depth \% in SL & 7.27 & $5.21-5.66$ \\
\hline
\end{tabular}

Table 2- Meristic characters of of S. javus and S. canaliculatus.

\begin{tabular}{|c|c|c|}
\hline Meristic characters & S. javus & S. canaliculatus \\
\hline Dorsal fin spines & 13 & 13 \\
\hline Dorsal fin rays & 10 & 10 \\
\hline Anal fin spines & 7 & 7 \\
\hline Anal fin rays & 9 & 9 \\
\hline Pectoral fin rays & 18 & 18 \\
\hline Pelvic fin spines & 2 & 2 \\
\hline Pelvic fin rays & 3 & 3 \\
\hline Gill rakers & 19 & $22-24$ \\
\hline
\end{tabular}

The environmental impacts may be the cause of range extension of S. javus in the Arabian Gulf and the Iraqi marine waters. Some of the environmental changes especially the salinity have always become a change in the composition of the assemblages. The environments of Iraqi marine waters are quite different compared with other parts of the Arabian Gulf. The Shatt Al-Arab River is considered as a major freshwater discharge into the northwest Arabian Gulf, and it plays an important role as feeding, nursery and protective grounds for many fish species $[13,14]$.

Most of the important characteristics that distinguish between Streaked rabbitfish $S$. javus and White-spotted rabbitfish $S$. canaliculatus are body depth $(54.01 \%$ in $S$. javus, $39.08-42.66 \%$ in $S$. canaliculatus), caudal peduncle depth ( $7.27 \%$ in $S$. javus, 5.21 to $5.66 \%$ in $S$. canaliculatus), gill rakers (19 in S. javus, 22-24 in S. canaliculatus) and The color (silvery blue undulating lines on mid and lower sides of the body in $S$. javus, numerous pearly blue to whitish spots on the nape and trunk in S. canaliculatus).

\section{Remarks}

Most of the characteristics in our results were consistent with the previous studies, with some differences in ranges of pectoral fin rays and ratio of body depth. Burhanuddin et al. [15] described 17 species of the family Siganidae from the coast of Sulawesi, Indonesia. They showed that the dorsal fin of Streaked rabbitfish contained 13 spines and 10 rays, anal fin contained seven spines and nine rays, pectoral fin 15-17 rays, body depth 2.0 to 2.3 times in standard length. Whereas White-spotted rabbitfish had 13 spines and 10 rays in dorsal fin, seven spines and nine rays in anal fin, 17-18 rays in pectoral fin, body depth 2.5 to 2.7 times in standard length.

\section{Conclusions}

The present record is a new addition to the marine fish species list for Iraq and indicates that suitable habitat for these species occurs in Iraqi waters.

\section{Acknowledgements}

We would like to thank Marine Science Centre, University of Basrah for giving us the opportunity to use the scientific facilities available. 


\section{References}

1. Fricke, R., Eschmeyer, W.N. and Fong, J.D. 2019. Species by family/subfamily in the Catalog of Fishes. California Academy of Sciences. www.calacademy.org (Updated 4 February 2019).

2. Nelson, J. S. 2006. Fishes of the World. $4^{\text {th }}$ Edition. John Wiley \& Sons Inc., New Jersey, xiv + $601 \mathrm{pp}$.

3. Carpenter, K.E. and Niem, V.H. 2001. FAO species identification guide for fishery purposes. The living marine resources of the Western Central Pacific. Volume 5. Bony fishes part 3 (Menidae to Pomacentridae). Rome, FAO. pp. 2791-3380.

4. Wassef, E. A. and Abdul Hady, H. 2001. Some Biological Studies and Gonadal Development of Rabbitfish Siganus canaliculatus (Park) and Siganus spinus L. (F: Siganidae) from the Gulf Waters off Saudi Arabia. J. KAU. Mar. Sci., 12(Special Issue): 189-208.

5. Mahdi, N. 1971. Additions to the marine fish fauna of Iraq. Iraq Nat. Hist. Mus. Publ. No. 28: 43 pp.

6. Hussain, N.A. and Naama, A.K. 1989. Survey of fish fauna of Khor Al-Zubair, north-west Arabian Gulf. Mar. Mesopot., 4(2): 161-197.

7. Mohamed, A.R.M., Hussain, N.A. and Ali, T.S. 2001. Estuarine components of the ichthyofauna of the Arabian Gulf. Mesopot. J. Mar. Sci. 16(2): 209-224.

8. Al-Faisal, A. J. and Mutlak, F. M. 2018. Survey of the marine fishes in Iraq. Bull. Iraq nat. Hist. Mus., 15(2): 163-177.

9. Carpenter, K.E., Krupp, F., Jones, D.A. and Zajonz U. 1997. FAO species identification guide for fishery purposes, The living marine resources of Kuwait, Eastern Saudi Arabia, Bahrain, Qatar, and the United Arab Emirates. Rome, FAO, 293 pp.

10. Taylor, W.R. 1970. Comment on the proposed validation of Siganus Forskal, 1775, and request that the name Teuthis Linnaeus (Pisces) be placed on the Official List of Generic Names in Zoology. Z. N.(S.)1721. Bulletin of Zoological Nomenclature, 26(5/6): 178-179.

11. Gill, T.N. 1884. Synopsis of the genera of the superfamily Teuthidoidea (families Teuthidae and Siganidae). Proceedings of the United States National Museum, 7: 275-281.

12. Kottelat, M. 2013. Comment on the proposed 'validation' of Siganus Forskål, 1775 (Pisces, Siganidae): awaiting a ruling since 1968. Bulletin of Zoological Nomenclature, 70(2): 114-120.

13. Al-Mudaffar, N.F. and Mahdi, B. A. 2014. Iraq's inland water quality and their impact on the North-Western Arabian Gulf. Marsh Bulletin, 9(1): 1-22.

14. Hussain, N. A., Mohamed A. R. M. and Ali. T. S. 1999. The seasonal formation of thermocline, halocline and water masses in the Iraqi marine waters. Marina Mesopotamica, 14(2): 299-312.

15. Burhanuddin A. I., Budimawan and Sahabuddin 2014. The rabbit-fishes (family Siganidae) from the coast of Sulawesi, Indonesia. International Journal of Plant, Animal and Environmental Sciences, 4(4): 95-102. 